\title{
The effect of forage-types on the fatty acid profile, lipid and protein oxidation, and retail colour stability of muscles from White Dorper lambs
}

\author{
Gerlane F. De Brito ${ }^{\mathrm{a}, \mathrm{b}}, *$, Benjamin W.B. Holman ${ }^{\mathrm{b}, \mathrm{d}}$, Shawn R. McGrath ${ }^{\mathrm{c}, \mathrm{d}}$, Michael A. Friend ${ }^{\mathrm{c}, \mathrm{d}}$, \\ Remy van de Ven ${ }^{\mathrm{e}}$, David L. Hopkins ${ }^{\mathrm{b}, \mathrm{d}}$

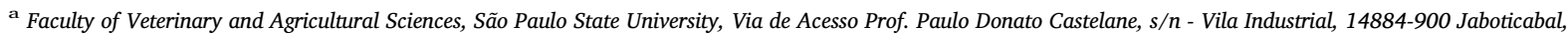 \\ Brazil \\ b Centre for Red Meat and Sheep Development, NSW Department of Primary Industries, Cowra, NSW 2794, Australia \\ c School of Animal and Veterinary Science, Charles Sturt University, Wagga Wagga, NSW 2650, Australia \\ d Graham Centre for Agricultural Innovation, Pugsley Place, Wagga Wagga, NSW 2650, Australia \\ e NSW Department of Primary Industries, Orange Agricultural Institute, Orange, NSW 2800, Australia
}

\section{A R T I C L E I N F O}

\section{Keywords:}

Oxidation status

Grazing

Chicory

adductor femoris

Lucerne

\begin{abstract}
A B S T R A C T
The aim of this study was to evaluate the effect of different forage-types on lamb meat quality parameters. White Dorper lambs that had grazed five forage-types, were slaughtered commercially. At $24 \mathrm{~h}$ post-mortem, the $m$. longissimus lumborum (LL) was removed from one side, sliced into three equal sub-samples, vacuum packaged and assigned to ageing periods $(5,12$ or 40 days); the other side of LL was aged for 5 days. The $m$. adductor femoris was used for fatty acid analysis. Lambs fed chicory + arrowleaf clover had the highest concentration of health claimable omega-3 fatty acids and the lowest omega-6:omega-3 fatty acid ratio. Forage-types with higher vitamin E content showed lower lipid oxidation levels independent of ageing period. Forage-type and ageing period did not influence the redness, yellowness, chroma or reflectance ratio $(630 \mathrm{~nm} \div 580 \mathrm{~nm})$ of displayed meat. Chicory + arrowleaf clover gave the best results to improve the fatty acid content of lamb meat.
\end{abstract}

\section{Introduction}

In recent years, the demand for food has changed and consumers are now increasingly concerned about its quality and healthiness (FAO, 2013). This change merits attention from producers and the adaptation of production systems to meet these emerging requirements. The fatty acid (FA) profile and content of meat plays an important role in human health. Fortunately, the nutritional manipulation of animal diets can provide a useful strategy to change or improve the FA composition in the meat (Zervas \& Tsiplakou, 2011). This offers an advantage to alternative approaches that use genetic improvement to optimise FA profiles, especially given the heritability estimates for FAs are considered of low to moderate heritability (Mortimer et al., 2014), in that nutritional management is comparatively faster.

Alteration of FA levels in meat has potential to influence oxidative stability (Wood \& Enser, 1997; Luciano et al., 2012), therefore also impact on the shelf life of meat. It is important that the effects of any new or novel feed types on the level of muscle FA and antioxidants such as vitamin $\mathrm{E}$ in meat are established. This will allow products that best meet market requirements in terms of quality and healthiness for human consumption to be produced (Ponnampalam et al., 2016).

The oxidative stability of meat is associated with many factors, including the balance between antioxidant and pro-oxidant components present in muscle (Descalzo \& Sancho, 2008). The polyunsaturated FA (PUFA) can act as the pro-oxidant component and lead to oxidative damage (Morrissey, Sheehy, Galvin, Kerry, \& Buckley, 1998). However, even at low concentrations, natural antioxidants (e.g. vitamin E) in meat can delay or inhibit the oxidative processes (Álvarez et al., 2009). The oxidative stability is dictated by the vitamin E content, being a natural antioxidant reported to improve the stability of lipids and colour in lamb meat (De La Fuente et al., 2007), and pastures, based mainly on green grasses, are rich sources vitamin $\mathrm{E}$ and other natural antioxidants (Ponnampalam et al., 2016).

Many studies have evaluated the composition and manipulation of meat FA through intensive (Ponnampalam, Trout, Sinclair, Egan, \& Leury, 2001; Hopkins et al., 2014) and extensive production systems (Cooper et al., 2004; Ponnampalam et al., 2010; Ponnampalam, Burnett, Norng, Warner, \& Jacobs, 2012) and some studies found that meat from lambs raised on pasture is considered to have a better quality in terms of PUFA profile (Fisher et al., 2000; Kitessa et al., 2010) and

\footnotetext{
* Corresponding author at: Prof. Paulo Donato Castellane, s/n - Vila Industrial, 14884-900 Jaboticabal, São Paulo, Brazil.

E-mail address: gerlaneferreira@zootecnista.com.br (G.F. De Brito).
} 
maintenance of oxidative stability (Luciano et al., 2012). Besides that, when well managed, grazing systems have economic potential and environmental advantages such as carbon sequestration, which can add value to land that cannot be used for other purposes (Robinson, Kerven, Behnke, Kushenov, \& Milner-Gulland, 2016), but this requires the control of vegetative growth by sustainable livestock production.

There are a number of novel forage-types about which there is no information on their effect on PUFA levels in meat and scientific verification is required. In the evaluation of five forage types it was recently reported (De Brito et al., 2016) that lambs fed on chicory + arrowleaf clover and those fed on lucerne were fatter at the same carcase weight than lambs fed on other forages, but there was no effect on intramuscular fat (IMF) levels in the two muscles tested. The question now is, what was the impact of these forages on muscle fatty acid levels, lipid oxidation and colour stability, especially given there are no published data on these traits in lambs fed these forage-types? Thus, the aim of this study was to evaluate the effect of different foragetypes on lamb vitamin E, fatty acids, lipid and protein oxidation and retail colour display in $m$. longissimus lumborum (LL) and $m$. adductor femoris (AF).

\section{Material and methods}

\subsection{Experimental design}

All animal procedures were approved by the Charles Sturt University Animal Care and Ethics Committee (Protocol No. 12/101). Experimental design and treatments were described by McGrath, Sandral, \& Friend (2015). Briefly, 62 weaned, mixed-sex (wether and ewe) White Dorper lambs grazed replicated (3 plots per forage-type) pastures sown to bladder clover (Trifolium spumosum cv. Bartolo) $(\mathrm{n}=12)$, hybrid forage brassica (Brassica napus cv. Stego) $(\mathrm{n}=12)$, lucerne (Medicago sativa cv. SARDI 10) $(\mathrm{n}=12)$, chicory (Cichorium intybus cv. Choice) + arrowleaf clover (Trifolium vesiculosum cv. Arrowtas) $(\mathrm{n}=15)$ and lucerne + phalaris (Phalaris aquatica cv. Advanced AT) $(\mathrm{n}=11)$ for 49 days from 15 of October to 2 of December 2014. The lambs were randomly distributed into plots (0.4 ha) with 3 replicates ( 3 plots per forage type) giving a total of 15 experimental plots and run with other lambs at a stocking rate of 32.5 lambs per hectare, where they remained for 49 days. The lambs were weighed initially $(34.4 \pm 5.6 \mathrm{~kg})$ and then thereafter weekly throughout the field experiment and finally two days prior to slaughter following an overnight curfew $(44.1 \pm 6.4 \mathrm{~kg}$ ) before then being returned to their assigned plots. Pluck samples were collected from pastures to reflect likely diet composition (Cook, 1964), dried at $70{ }^{\circ} \mathrm{C}$ for $48 \mathrm{~h}$ and tested for metabolisable energy (ME) and crude protein (CP) using NIR spectroscopy (Table 1) (CSIRO, 2007). Lambs were grazing pastures late in the pasture growing season (late spring), a period when annual pastures in southern NSW typically start to senesce and decline in quality. Feed samples were collected weekly during the feeding period for assessment of forage type vitamin $\mathrm{E}$ (Vit_E) and FA content (Table 1). More specific details on experimental design, sampling of pastures, treatments and slaughter have been described by McGrath et al. (2015)) and De Brito et al. (2016).

\subsection{Sampling}

The carcases weighed on average $23.1 \pm 4.0 \mathrm{~kg}$ hot carcass weight with a GR tissue depth of $11.9 \pm 5.2 \mathrm{~mm}$. The carcasses remained in the chillers $\left(3-4{ }^{\circ} \mathrm{C}\right)$ for $24 \mathrm{~h}$ post-slaughter before the topside (Product identification number HAM 5073; Anonymous, 2005) was removed from the right side and the LL muscle was removed from the both sides (Product identification number HAM 4910; Anonymous, 2005). The boned LLs and topsides were transported to the Centre for Red Meat and Sheep Development (NSW Dept. of Primary Industries, Cowra, New South Wales, Australia). Each entire LL from the left side was divided
Table 1

Composition of crude protein (CP, g/kg DM), metabolisable energy (ME, MJ/kg DM), and neutral detergent fiber (NDF, g/kg DM), vitamin E (Vit_E, mg alpha tocopherol $/ \mathrm{kg}$ ), saturated fatty acid (SFA, g/100 $\mathrm{g}$ feed lipid), polyunsaturated fatty acid (PUFA, g/100 g feed lipid), monounsaturated fatty acid (MUFA, g/100 g feed lipid), Alpha linolenic acid (C18:3 $\omega 3$ - ALA, g/100 g feed lipid), omega-3 ( $\omega-3, g / 100 \mathrm{~g}$ feed lipid), omega- 6 ( $\omega-6$, $\mathrm{g} / 100 \mathrm{~g}$ feed lipid) of five forage-types used to graze lambs.

\begin{tabular}{|c|c|c|c|c|c|}
\hline Date & Bladder & Brassica & Chic/arrow & luc/phal & Lucerne \\
\hline \multicolumn{6}{|l|}{$\mathrm{CP}$} \\
\hline October $(29 / 10)$ & 19.1 & 22.5 & 30.5 & 19.0 & 29.0 \\
\hline November $(13 / 11)$ & 14.4 & 16.3 & 20.2 & 11.9 & 23.8 \\
\hline December $(26 / 11)$ & 16.0 & 10.9 & 16.4 & 18.1 & 22.5 \\
\hline \multicolumn{6}{|l|}{ ME } \\
\hline October $(29 / 10)$ & 11.2 & 11.0 & 12.5 & 9.6 & 12.8 \\
\hline November (13/11) & 9.2 & 8.4 & 11.5 & 8.0 & 11.7 \\
\hline December $(26 / 11)$ & 8.4 & 5.6 & 10.4 & 7.7 & 10.8 \\
\hline \multicolumn{6}{|l|}{ NDF } \\
\hline October $(29 / 10)$ & 37.1 & 17.6 & 34.8 & 48.7 & 33.5 \\
\hline November $(13 / 11)$ & 47.8 & 35.6 & 38.4 & 56.4 & 40.8 \\
\hline December $(26 / 11)$ & 60.3 & 51.1 & 41.7 & 58.2 & 43.4 \\
\hline \multicolumn{6}{|l|}{ Vit_E } \\
\hline October $(29 / 10)$ & 4.87 & 10.97 & 6.14 & 27.60 & 10.93 \\
\hline November $(13 / 11)$ & 5.13 & 10.21 & 3.42 & 6.20 & 6.86 \\
\hline December $(26 / 11)$ & 8.38 & 16.72 & 11.08 & 5.01 & 9.92 \\
\hline \multicolumn{6}{|l|}{ SFA } \\
\hline October (29/10) & 42.74 & 25.17 & 29.64 & 30.59 & 40.08 \\
\hline November (13/11) & 32.16 & 28.76 & 34.80 & 37.92 & 45.15 \\
\hline November $(26 / 11)$ & 26.86 & 11.71 & 37.12 & 32.52 & 43.55 \\
\hline \multicolumn{6}{|l|}{ PUFA } \\
\hline October $(29 / 10)$ & 46.80 & 69.13 & 61.95 & 63.24 & 51.33 \\
\hline November $(13 / 11)$ & 57.94 & 60.17 & 59.28 & 55.60 & 47.80 \\
\hline November $(26 / 11)$ & 57.20 & 32.64 & 56.05 & 58.91 & 47.91 \\
\hline \multicolumn{6}{|l|}{ MUFA } \\
\hline October $(29 / 10)$ & 10.46 & 5.69 & 8.41 & 6.16 & 8.58 \\
\hline November $(13 / 11)$ & 9.91 & 11.07 & 5.92 & 6.49 & 7.06 \\
\hline November $(26 / 11)$ & 15.95 & 55.65 & 6.83 & 8.58 & 8.55 \\
\hline \multicolumn{6}{|l|}{ C18:3 $\omega-3$ ALA } \\
\hline October $(29 / 10)$ & 16.39 & 48.48 & 47.40 & 46.71 & 31.88 \\
\hline November $(13 / 11)$ & 11.83 & 35.07 & 39.40 & 38.17 & 27.7 \\
\hline November $(26 / 11)$ & 7.64 & 13.62 & 32.78 & 41.65 & 28.46 \\
\hline \multicolumn{6}{|l|}{$\omega-3$} \\
\hline October $(29 / 10)$ & 17.22 & 54.55 & 47.72 & 46.71 & 32.67 \\
\hline November (13/11) & 12.70 & 42.08 & 40.21 & 38.21 & 28.44 \\
\hline November $(26 / 11)$ & 8.84 & 16.00 & 33.39 & 41.65 & 29.03 \\
\hline \multicolumn{6}{|l|}{$\omega-6$} \\
\hline October $(29 / 10)$ & 29.59 & 14.58 & 14.23 & 16.54 & 18.67 \\
\hline November $(13 / 11)$ & 45.24 & 18.10 & 19.06 & 17.39 & 19.35 \\
\hline November $(26 / 11)$ & 48.36 & 16.65 & 22.66 & 17.26 & 18.87 \\
\hline
\end{tabular}

$\mathrm{ME}=0.203 \times$ DOMD -3.001 (Packer, Clayton, \& Cusack, 2011).

into three equal samples, vacuum packaged and assigned randomly to ageing periods of 5,12 and 40 days, so that each LL was represented in each period and the ageing occurred under refrigeration (mean: $1.6^{\circ} \mathrm{C}$ ) for subsequent analysis of retail colour display, thiobarbituric acid reactive substances (TBARS), and nitrate, nitrite and carbonyl content. A $25 \mathrm{~g}$ sample of LL from the right side was removed and frozen at $-20{ }^{\circ} \mathrm{C}$ for later measurement of vitamin $\mathrm{E}$ content. The $\mathrm{m}$. adductor femoris was removed from each topside and as for each right side LL, a portion (approximately $30 \mathrm{~g}$ ) was sampled, freeze-dried and stored at $-20{ }^{\circ} \mathrm{C}$ for determination of FA profile measured in AF muscle not aged.

\subsection{Fatty acid profile}

Freeze dried ground samples $(0.5 \mathrm{~g})$ were taken from the $\mathrm{AF}$ and $\mathrm{LL}$ muscles for FA extraction, using a rapid modified procedure described by Ponnampalam et al. (2014). Briefly, the samples were ground and one ml of tridecanoic acid (C13:0, Sigma Aldrich Pty Ltd., Castle Hill, NSW 2154, 
Australia) was added to muscle samples as an internal standard dissolved in methanol $(0.5 \mathrm{mg}$ of $\mathrm{C} 13: 0 / \mathrm{ml}$ of methanol). The contents were hydrolysed using $0.7 \mathrm{ml}$ of $10 \mathrm{~N} \mathrm{KOH}$ in water and $5.3 \mathrm{ml}$ of methanol to form free FAs. After mixing well with a vortex, the contents were incubated at $55^{\circ} \mathrm{C}$ in water bath for $1.5 \mathrm{~h}$, with vigorous hand-shaking for $5 \mathrm{~s}$ at $20 \mathrm{~min}$ intervals. The contents were mixed with $0.58 \mathrm{ml}$ of $24 \mathrm{~N}$ sulphuric acid $\left(\mathrm{H}_{2} \mathrm{SO}_{4}\right)$ in water and cooled in tube. After cooling the tubes to room temperature, they were mixed by inversion and incubated for $1.5 \mathrm{~h}$. Three (3) $\mathrm{ml}$ of hexane and $1 \mathrm{ml}$ of saturated sodium chloride were added to the cooled tube (below room temperature) and vortexed for $5 \mathrm{~min}$. A portion of the fatty acid methyl ester (FAME) solution was put into an auto sampler vial for analysis. The Gas Chromotograph (GC) conditions were: column $60 \mathrm{~m} \times 0.25 \mathrm{~mm}$, ID 70\% Cyanopropyl Polysilphenylene-siloxane with $0.25 \mu \mathrm{m}$ of BPX-70 (SGE) and Column oven program was: BPX-70:100 ${ }^{\circ} \mathrm{C}$ for $0.5 \mathrm{~min}$, temperature program at $20^{\circ} \mathrm{C} /$ min to $130^{\circ} \mathrm{C}$, hold isothermally for $2 \mathrm{~min}$, temperature program at $1{ }^{\circ} \mathrm{C} /$ min to $150{ }^{\circ} \mathrm{C}$, hold isothermally for $3 \mathrm{~min}$, temperature program at $3{ }^{\circ} \mathrm{C} /$ min to $220^{\circ} \mathrm{C}$, hold isothermally for $6 \mathrm{~min}$. The total amount of eicosapentaenoic acid (EPA) and docosahexaenoic acid (DHA) (EPA + DHA), total $\omega-3$, total omega 6 ( $\omega-6)$, saturated FA (SFA), monounsaturated FA (MUFA), PUFA, and $\omega-3: \omega-6$ ratio were calculated as the sum from the FA profiles of GC quantification. All FA concentration was expressed in $\mathrm{mg} / 100 \mathrm{~g}$ of meat.

\subsection{Lipid oxidation and vitamin $E$}

The lipid oxidation was assessed by the TBARS procedure following retail display. A $1 \mathrm{~g}$ sample of each LL within each ageing period was removed. TBARS content determination was adapted from Hopkins et al. (2014) with $50.0 \mathrm{mg}$ sample added to $500.0 \mu \mathrm{L}$ RIPA buffer (no. 10010263, RIPA buffer concentrate, Cayman Chemicals, Michigan, USA) and homogenized using micro-tube pestles. The supernatant was then analysed as per the OXltek TBARS assay kit technical bulletin (Zeptometrix, 2006) and absorbance read at $532 \mathrm{~nm}$ on a bench top spectrophotometer. Results were expressed as mg malondialdehyde (MDA) per $\mathrm{kg}$ fresh meat. The concentration of vitamin $\mathrm{E}$ in the treatment rations and muscle was analysed using methods described previously by McMurray and Blanchflower (1979).

\subsection{Carbonyl content}

Approximately $1.0 \mathrm{~g}$ of tissue was removed from each sample following the ageing periods and kept at $-80{ }^{\circ} \mathrm{C}$ until analysis. Each sample was added to $4 \mathrm{ml}$ of ice-cold tissue lysis buffer (Cold Spring Harbor Protocols, 2009) and then homogenized for two bursts $(22,000 \mathrm{rpm})$ of $15 \mathrm{~s}$ (Ystral homogeniser: Series $\times 10 / 25$, Ystral, Germany), followed by centrifugation (Model CPR, Bechman Instruments, CA: USA) at $3500 \mathrm{rpm}$ for $15 \mathrm{~min}$. The supernatant was then analysed using the colorimetric protocol detailed by Protein Carbonyl Assay Kit (Sigma-Aldrich, MO:USA; Catalogue No. MAK094) technical bulletin (Sigma-Aldrich, 2015b) using a micro-plate reader (FLUOstar OPTIMA, BMG, Labtechnologies, VIC:AUS) measuring absorbance at $375 \mathrm{~nm}$. Samples were tested as technical duplicates.

\subsection{Nitrite and nitrate content}

Both nitrate and nitrite content were tested using approximately $1.0 \mathrm{~g}$ of tissue removed from each sample following the ageing period and kept at $-80^{\circ} \mathrm{C}$ until analysis. Each sample was added to $25 \mathrm{ml}$ of ice-cold Milli$\mathrm{Q}$ water and then homogenized for two bursts (22,000 rpm) of $15 \mathrm{~s}$ (Ystral homogeniser: Series $\times 10 / 25$, Ystral, Germany), followed by centrifugation (Model CPR, Bechman Instruments, CA: USA) at $3500 \mathrm{rpm}$ for $15 \mathrm{~min}$. The supernant was then compared against nitrate and nitrate + nitrite standards using the colorimetric protocol detailed by the nitrite/nitrate Assay Kit (Sigma-Aldrich, MO:USA; Catalogue No. 23479) technical bulletin (Sigma-Aldrich, 2015a) and using a micro-plate reader (FLUOstar
OPTIMA, BMG, Labtechnologies, VIC:AUS) measuring absorbance at $540 \mathrm{~nm}$. Samples were tested as technical duplicates and nitrite content was calculated by subtracting nitrate from nitrate + nitrite results.

\subsection{Retail display colour}

Following their prescribed ageing period, a cutting guide was used to section the LL samples to a uniform $3 \mathrm{~cm}$ thickness with the myofibrils perpendicular on the measured surface. These sections were then individually placed on black foam trays and overwrapped with PVC food film wrap $(15 \mu \mathrm{m})$ and permitted to bloom for $45 \mathrm{~min}$ before colorimetric analysis. Colorimetric measurements were taken over four display time intervals $(0,24,48$, and $72 \mathrm{~h})$ between which all samples were displayed under simulated retail lighting (mean: $851 \mathrm{~lx}$ ) and refrigeration (mean: $1.6{ }^{\circ} \mathrm{C}$ ). A HunterLab spectrophotometer (Miniscan Model 45/0-L: Reston, VA, USA) with a $25 \mathrm{~mm}$ aperture was calibrated as per manufacturer guidelines $(\mathrm{X}=80.4, \mathrm{Y}=85.3, \mathrm{Z}=91.5)$. This was set to illuminant D-65 and viewing angle $10^{\circ}$. At each reading, measurements were replicated after rotating the spectrophotometer $90^{\circ}$ in the horizontal plane. The oxymyoglobin/metmyoglobin ratio (R630/ 580) was estimated by dividing the captured light reflectance at wavelength $630 \mathrm{~nm}$, by that at wavelength $580 \mathrm{~nm}$ (AMSA, 2012). The metmyoglobin (MMb), deoxymyoglobin (DMb) and oxymyoglobin $(\mathrm{OMb})$ were estimated using the equations from AMSA guidelines (AMSA, 2012), the reflectance ( $\mathrm{R}$ - oxymyoglobin/metmyoglobin ratio) was converted to reflex attenuance (A - logarithm of the reciprocal of reflectance) using Eq. (1) followed by insertion of the A-value in the Eqs. (2) to (4) to calculate MMb, DMb and OMb values in percentage (\%).

$$
A=\log \frac{1}{R}
$$

$\mathrm{MMb}=\left\{1.395-\left[\frac{(A 572-A 730)}{(A 525-A 730)}\right]\right\} \times 100$

$\mathrm{DMb}=\left\{2.375 x\left[1-\frac{(A 473-A 730)}{(A 525-A 730)}\right]\right\} \times 100$

$\mathrm{OMb}=100-(\mathrm{MMb}+\mathrm{DMb})$

\subsection{Statistical analyses}

The FA's were analysed separately using linear mixed model (LMM) methods. The model fitted for each FA had fixed effects for sex (wether and ewe), forage-type (bladder, brassica, chicory + arrowleaf clover, lucerne + phalaris and lucerne), muscles (AF and LL) and forage-type $x$ muscle interaction. Animal (62 animals), plot (3 plots per forage-type) and error were fitted as random effects. For TBARS (AF samples only) and vitamin $\mathrm{E}$ the fitted model had sex and forage-type as fixed effects and plot and error as random effects. For analysis of TBARS (LL samples), carbonyl, nitrate and nitrite content a LMM regression analysis as undertaken for each trait separately. For each the full fitted model had fixed effects (sex, forage-type and ageing period). Random effects were, forage-type $\mathrm{x}$ ageing period interaction, plot, animal, random error and, for carbonyl and nitrite/nitrate content only, batch $\mathrm{x}$ ageing period interaction. The LMM model used to analyse each colour trait (excluding $\mathrm{MMb}, \mathrm{DMb}$ and $\mathrm{OMb}$ ) for each ageing period had as fixed effects forage-type, display period $(0,1,2$, or 3 days) and foragetype $\mathrm{x}$ display period. The sex effect was ignored as it was not significant for most colour traits, and where there was an effect it was marginal. Random effects were random regressions on display time across plots and across animals within plots, and random error. MMb and $\mathrm{DMb}$ were analysed jointly for each ageing period separately as a bivariate response, noting that $\mathrm{OMb}=100-(\mathrm{MMb}+\mathrm{DMb})$. The multivariate linear mixed model included fixed effects for trait (MMb 


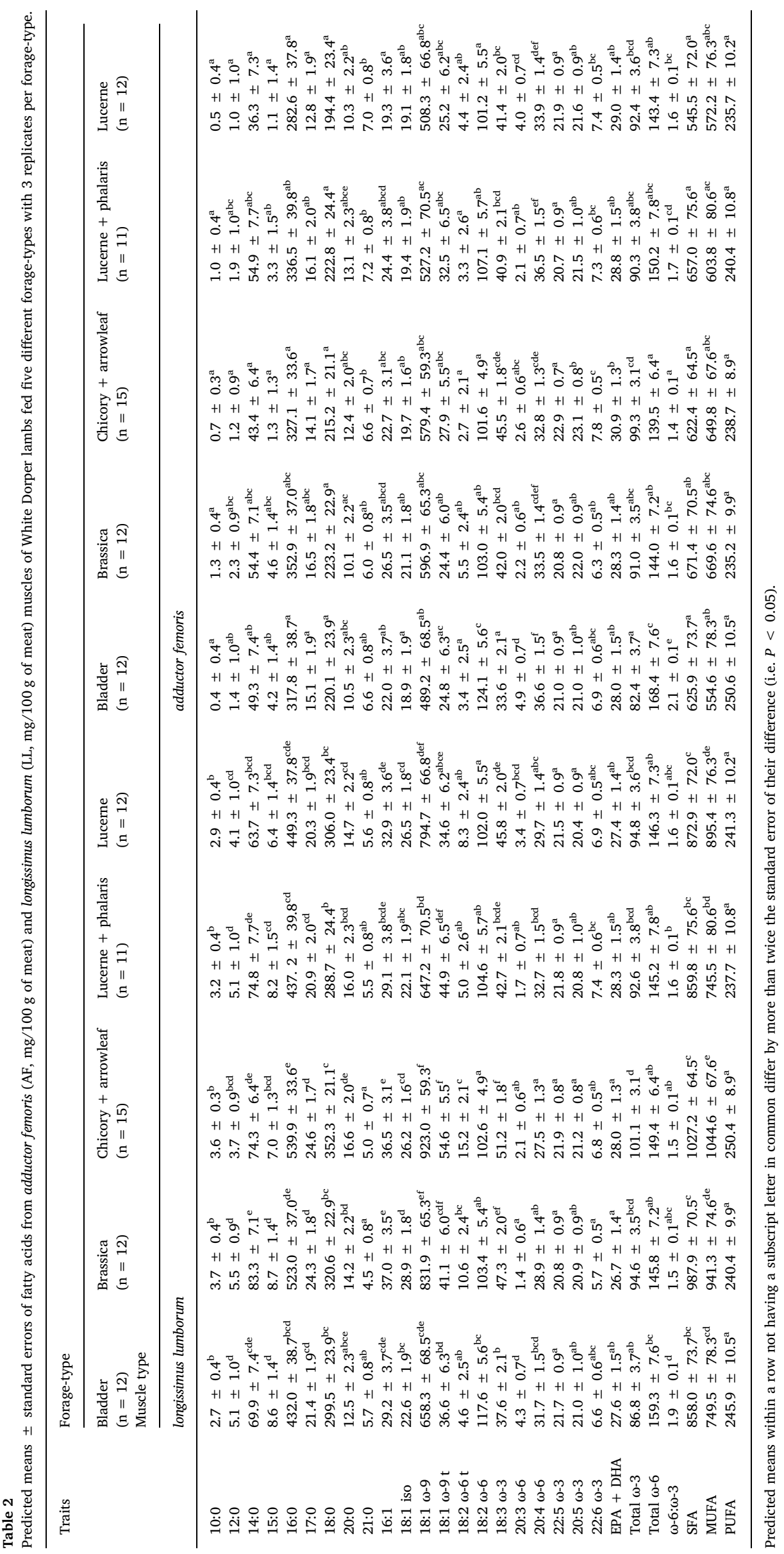


Table 3

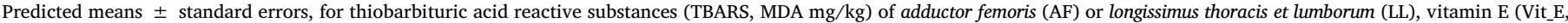

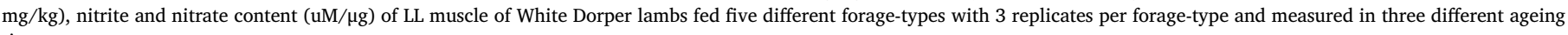
times.

\begin{tabular}{|c|c|c|c|c|c|c|}
\hline \multirow[t]{2}{*}{ Traits } & \multirow[t]{2}{*}{ Days aged } & \multicolumn{5}{|l|}{ Treatments } \\
\hline & & $\begin{array}{l}\text { Bladder } \\
(\mathrm{n}=12)\end{array}$ & $\begin{array}{l}\text { Brassica } \\
(n=12)\end{array}$ & $\begin{array}{l}\text { Chic/arrow }{ }^{1} \\
(n=15)\end{array}$ & $\begin{array}{l}\text { luc/phal } \\
(\mathrm{n}=11)\end{array}$ & $\begin{array}{l}\text { Lucerne } \\
(\mathrm{n}=12)\end{array}$ \\
\hline TBARS_AF & 0 & $3.0 \pm 0.2^{\mathrm{b}}$ & $2.3 \pm 0.2^{\mathrm{a}}$ & $3.1 \pm 0.1^{\mathrm{b}}$ & $2.3 \pm 0.2^{\mathrm{a}}$ & $2.9 \pm 0.2^{\mathrm{b}}$ \\
\hline \multirow[t]{3}{*}{ TBARS_LL } & 5 & $1.8 \pm 0.2^{\mathrm{c}}$ & $1.3 \pm 0.2^{\mathrm{ab}}$ & $1.7 \pm 0.1^{\mathrm{bc}}$ & $1.3 \pm 0.2^{\mathrm{a}}$ & $1.8 \pm 0.2^{\mathrm{c}}$ \\
\hline & 12 & $3.1 \pm 0.2^{\mathrm{f}}$ & $2.6 \pm 0.2^{\mathrm{de}}$ & $3.0 \pm 0.1$ ef & $2.6 \pm 0.2^{\mathrm{d}}$ & $3.0 \pm 0.2^{\mathrm{f}}$ \\
\hline & 40 & $4.4 \pm 0.2^{\mathrm{i}}$ & $4.0 \pm 0.2^{g h}$ & $4.3 \pm 0.1^{\mathrm{hi}}$ & $3.9 \pm 0.2^{g}$ & $4.5 \pm 0.2^{\mathrm{i}}$ \\
\hline Vit_E & 0 & $2.2 \pm 0.3^{\mathrm{a}}$ & $3.7 \pm 0.3^{\mathrm{c}}$ & $2.7 \pm 0.2^{\mathrm{ab}}$ & $3.2 \pm 0.3^{\mathrm{bc}}$ & $2.5 \pm 0.3^{\mathrm{ab}}$ \\
\hline \multirow[t]{3}{*}{ Nitrite } & 5 & $3.3 \pm 0.9^{\mathrm{a}}$ & $3.5 \pm 0,9^{\mathrm{a}}$ & $3.4 \pm 0.9^{\mathrm{a}}$ & $3.5 \pm 0.9^{\mathrm{a}}$ & $3.5 \pm 0.9^{\mathrm{a}}$ \\
\hline & 12 & $15.7 \pm 5.1^{b}$ & $16.9 \pm 5.4^{\mathrm{b}}$ & $16.0 \pm 5.1^{b}$ & $16.8 \pm 5.4^{\mathrm{b}}$ & $16.5 \pm 5.3^{\mathrm{b}}$ \\
\hline & 40 & $21.8 \pm 7.0^{\mathrm{b}}$ & $23.4 \pm 7.5^{\mathrm{b}}$ & $22.2 \pm 7.1^{b}$ & $23.3 \pm 7.5^{\mathrm{b}}$ & $22.9 \pm 7.3^{\mathrm{b}}$ \\
\hline \multirow[t]{3}{*}{ Nitrate } & 5 & $2.7 \pm 1.2^{\mathrm{a}}$ & $4.0 \pm 1.8^{\mathrm{abc}}$ & $3.6 \pm 1.6^{\mathrm{ab}}$ & $4.8 \pm 2.1^{\mathrm{bcd}}$ & $3.3 \pm 1.5^{\mathrm{ab}}$ \\
\hline & 12 & $30.0 \pm 16.0^{\mathrm{ef}}$ & $40.7 \pm 21.7^{\mathrm{ef}}$ & $31.9 \pm 17.0^{\mathrm{ef}}$ & $43.5 \pm 23.3^{\mathrm{fg}}$ & $30.5 \pm 16.4^{\mathrm{ef}}$ \\
\hline & 40 & $10.3 \pm 5.5^{\text {bce }}$ & $14.3 \pm 7.7^{\text {cdeg }}$ & $11.4 \pm 6.1^{\text {bcdeg }}$ & $17.4 \pm 9.3^{\mathrm{df}}$ & $10.5 \pm 5.6^{\text {bceg }}$ \\
\hline
\end{tabular}

Predicted means for a Trait $\mathrm{x}$ Days aged not having a subscript letter in common differ by more than twice the standard error of their difference (i.e. $P<0.05$ ).

${ }^{1}$ chic/arrow - chicory + arrowleaf clover.

${ }^{2}$ luc/phal - lucerne + phalaris.

or $\mathrm{DMb}$ ), forage type, display period and interactions between these factors. Random effects, for each trait, were effects for plot, plot $\mathrm{x}$ display period, and animal. Random errors for each sample were modelled as independent, but correlated within samples. The traits were analysed using R Core Team (2015), and predicted means were compared by least significant difference (LSD) at the $5 \%$ level.

\section{Results}

\subsection{Fatty acid profile}

Thirty three (33) FA in the AF and LL muscle were analysed, however 5 of those $(4: 0,8: 0,20: 1,18: 3 \omega-6$ and 20:2 $\omega-6)$ were removed from the analysis due to negligible detection levels. The FA profiles of AF and LL muscles are summarised in Table 2. There was very limited evidence for significant muscle $\mathrm{x}$ forage-type interactions $(P<0.05)$ for most FAs, and for the few with a significant interaction the evidence was not strong $(P>0.01)$. The decanoic acid (10:0), lauric acid (12:0), myristic acid (14:0), pentadecanoic acid (15:0), palmitic acid (16:0), margaric acid (17:0), stearic acid (18:0) and arachidic acid (20:0). FAs were greater for LL muscle than for AF muscle independent of forage-type, except for heneicosanoic acid (21:0) which was greater for AF muscle than for LL muscle. The LL from lambs fed brassica showed the highest content of 10:0, 12:0, 14:0 and 15:0 fatty acids, whereas the level of longer chain SFA including 16:0, 17:0, 18:0 and 20:0 was higher in lambs fed chicory + arrowleaf clover. The AF muscle from lambs fed lucerne had the lowest levels of most of the SFA, except for 10:0, 20:0 and 21:0.

Significant muscle and/or forage-type effects $(P<0.05)$ were observed for most of the mono-unsaturated FAs (MUFA) and PUFA, including the health claimable EPA + DHA, total $\omega-3$, total $\omega-6$ and $\omega$ 6: $\omega-3$ ratio (Table 2). The linoleic acid (18:2 $\omega-6$ LA) content was higher in lambs fed bladder clover, for both muscle types. Lambs fed chicory + arrowleaf clover or brassica had the highest concentration of alpha linolenic (18:3 $\omega$-3 ALA) FA in the LL muscle, while the lowest concentration of 18:3 $\omega$-3 ALA in the AF muscle was from lambs fed bladder clover. Both EPA (eicosapentaenoic acid) and DHA (docosahexaenoic acid) were higher in AF than in LL muscle, independent of the forage-type. Besides that, EPA and DHA were greater for AF muscle of lambs fed chicory + arrowleaf clover however, for EPA this treatment was different only from LL muscle of lambs fed chicory + arrowleaf clover and lucerne, whereas for DHA, this treatment was different only from LL muscle of lambs fed chicory + arrowleaf clover and LL and AF muscles of lambs fed brassica for DHA. Similarly, the concen- tration of health claimable EPA + DHA was greater in the AF than in LL muscle and AF muscle from lambs fed chicory + arrowleaf clover had the highest EPA + DHA content, differing only to LL muscles from lambs fed brassica and chicory + arrowleaf clover. Total $\omega-3$ was higher for LL muscle than for AF muscle, independent of the foragetype. The highest level of total $\omega-3$ was found in LL and AF muscle of lambs fed chicory + arrowleaf clover and the lowest in the same muscles of lambs fed bladder clover with the reciprocal of these results for total $\omega-6$ in the AF muscle.

The concentration of total muscle SFA and MUFA differed significantly across muscle type $(P<0.001)$. This was not true for the concentration of total muscle PUFA. The level of total SFA was much greater for LL muscle compared to AF muscle independent of foragetype. The levels of MUFA were greater for LL muscle from lambs fed chicory + arrowleaf clover, brassica and lucerne than for the other muscles and forage-types.

\subsection{Lipid oxidation, vitamin $E$, carbonyl, nitrite and nitrate content}

The concentration of TBARS in AF muscle, measured only on samples aged for 0 days, was higher for lambs fed chicory + arrowleaf clover, bladder clover and lucerne than for others forage-types, with no significant differences between them (Table 3). Significant changes in TBARS over the ageing periods were found within LL muscles $(P<0.001)$ with an increase with ageing. Highest TBARS values were found in LL muscle aged for 40 days compared to muscle aged for 5 or 12 days. In general, highest TBARS values at 5, 12 and 40 days aged were observed in meat of lambs fed bladder clover, chicory + arrowleaf clover and lucerne.

There was a forage-type difference $(P<0.05)$ in LL muscle for vitamin E concentration (Table 3). Higher vitamin E concentration was found in lambs fed brassica than the other forage-types, however lambs fed lucerne + phalaris had a vitamin E concentration statistically equal to lambs fed brassica. A non-significant forage-type and ageing time effect $(P>0.05)$ was found for carbonyl content. The carbonyl predicted means \pm standard errors for $L L$ muscle aged 5 and 40 days, respectively, are: bladder clover $(2.70 \pm 0.44 ; 3.02 \pm 0.44)$, brassica $(2.87 \pm 0.44 ; 2.99 \pm 0.44)$, chicory + arrowleaf clover $(3.16 \pm 0.43 ; 2.92 \pm 0.43)$, lucerne + phalaris $(2.87 \pm 0.45 ; 3.34 \pm 0.44)$ and lucerne $(2.89 \pm 0.44 ; 2.98 \pm 0.44)$.

The predicted means for nitrite and nitrate are presented in Table 3. Of the effects associated with forage-type and ageing, only ageing was significant and only for nitrite $(P=0.02)$ with an increase in nitrite content in LL muscle over ageing time for all forage-types. Higher nitrite content was observed in LL muscle aged for 40 days than for 12 
and 5 day aged samples, respectively. Intermediary nitrite values were observed in LL muscle at 12 days aged however, the content of nitrite in meat aged at 40 and 12 days was statistically similar, partly reflecting an increase in variance in the trait. For Nitrate the ageing effect was significant at $P=0.06$. Forage-type's, averaged over ageing periods, were not significantly different for either nitrite or nitrate $(P=0.88$ and $P=0.29$ respectively), but there was some variation in the ageing differences across forage-types for Nitrate. The nitrate content in LL muscle increased from 5 days to 12 days aged, decreasing at 40 days aged. The lowest nitrate content was found in LL muscle of lambs fed bladder clover, however this forage-type was significantly similar to all the others forage-type 5 days aged, except for lucerne + phalaris also aged for 5 days. Whereas, the highest nitrate content was observed for LL muscle aged for 12 days from lambs fed lucerne + phalaris nevertheless, it was statistically similar to LL muscle 12 days aged of lambs fed all forage-types plus LL muscle 40 days aged of lambs fed lucerne + phalaris.

\subsection{Retail display colour}

For colour traits lightness $\left(\mathrm{L}^{*}\right)$, redness $\left(\mathrm{a}^{*}\right)$, yellowness $\left(\mathrm{b}^{*}\right)$, Chroma, Hue and R630/580 there were no significant sex effects across any ageing time $(5,12$ or 40 days). There were also no significant interaction effects between forage-type and display period for these colour traits at any of the ageing times except for hue of 12 day aged samples $(P=0.01)$. This significant interaction effect for hue can most likely be attributable to chance alone given the number tests performed. For each of the colour traits ( $L^{*}, a^{*}, b^{*}$ Chroma, Hue and R630/580) there were significant $(P<0.001)$ display period effects within each ageing time, and significant forage type effects for $\mathrm{L}^{*}$ and hue $(P=0.01$ for samples aged 5 and 12 days, $P=0.05$ for samples aged 40 days). Predicted means for colour trait $\mathrm{x}$ ageing time's, averaged over display periods, are given in Table 4 for each forage type, together with the associated standard errors and an LSD Ranking across forage types within each colour trait $\mathrm{x}$ ageing time.

The lightness of LL muscle decreased from 5 to 12 days aged and increased at 40 days aged, with lighter meat for muscle aged 40 days than for 5 and 12 days, respectively. Lambs fed chicory + arrowleaf clover had lighter $\left(\mathrm{L}^{*}\right)$ meat for all ageing periods than all other foragetypes. The redness ( $\mathrm{a}^{*}$ ) of LL muscle increased from 5 to 12 days and decreased at 40 days aged. A significant difference between the foragetypes was observed only for muscles aged for 12 days, with higher redness for lambs fed brassica, however only with a difference from the lambs fed chicory + arrowleaf clover that showed the lowest a* values. Whereas, lambs fed chicory + arrowleaf clover showed the highest yellowness $\left(b^{*}\right)$ and Hue values for all ageing times compared to the other forage-types. The ratio (R630/580) values were higher for LL muscle aged for 12 days compared to that age for 5 or 40 days, respectively. No significant differences between the forage-types were observed for ratio when muscles were aged for 5 days (Table 4). Whereas, LL muscles aged for 12 and 40 days from lambs fed brassica had higher ratio values, however, the hue value of muscle after 12 days aged for lambs fed brassica differed only from chicory + arrowleaf clover and lucerne, while hue values of muscle 40 days aged from lambs fed brassica differed only from the lambs fed chicory + arrowleaf clover.

For $\mathrm{MMb}$ and $\mathrm{DMb}$ there were significant $(P<0.01)$ forage-type $\mathrm{x}$ display period interaction effects for both 5 day aged samples, and for $\mathrm{DMb}$ for 40 day aged samples (Table 5). This interaction effect was not significant $(P>0.05)$ for MMb and DMb for 12 day aged samples, or for $\mathrm{MMb}$ from 40 day aged samples. Lambs fed bladder clover had the highest concentration of MMb in LL muscle after 3 days of display for all ageing times and a lower MMb concentration in LL muscle at the start of display (0 days) for all ageing periods compared to the other forage-types and display periods. This same forage-type also had the highest $\mathrm{DMb}$ concentration at the start of display time (0 days) for all ageing periods. A higher DMb concentration was observed in LL muscle aged for 5 days, 0 days displayed for lambs fed bladder clover than for the other treatments. Whereas, a lower DMb concentration was found in LL muscle aged for 40 days, after 2 days of display for lambs fed lucerne than for the other treatments. The OMb concentration was higher in LL muscle aged for 12 days, after 1 day of display for lambs fed chicory

Table 4

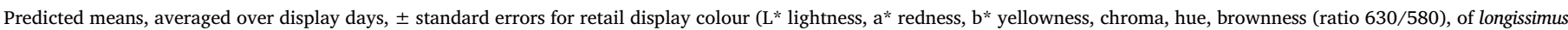
thoracis et lumborum (LL) muscle of White Dorper lambs fed five different forage-types with 3 replicates per forage-type and measured in three ageing times.

\begin{tabular}{|c|c|c|c|c|c|}
\hline \multirow[t]{2}{*}{ Traits } & \multicolumn{5}{|l|}{ Treatments } \\
\hline & $\begin{array}{l}\text { Bladder } \\
(\mathrm{n}=12)\end{array}$ & $\begin{array}{l}\text { Brassica } \\
(\mathrm{n}=12)\end{array}$ & $\begin{array}{l}\text { Chic/arrow }{ }^{1} \\
(\mathrm{n}=15)\end{array}$ & $\begin{array}{l}\text { luc/phal } \\
(\mathrm{n}=11)\end{array}$ & $\begin{array}{l}\text { Lucerne } \\
(\mathrm{n}=12)\end{array}$ \\
\hline \multicolumn{6}{|l|}{5 days aged } \\
\hline $\mathrm{L}^{*}$ & $36.4 \pm 0.5^{\mathrm{a}}$ & $36.8 \pm 0.5^{\mathrm{a}}$ & $39.2 \pm 0.5^{\mathrm{b}}$ & $37.3 \pm 0.5^{\mathrm{a}}$ & $37.5 \pm 0.5^{\mathrm{a}}$ \\
\hline$a^{*}$ & $17.5 \pm 0.4^{\mathrm{a}}$ & $18.2 \pm 0.4^{\mathrm{a}}$ & $18.0 \pm 0.4^{\mathrm{a}}$ & $17.4 \pm 0.4^{\mathrm{a}}$ & $18.3 \pm 0.4^{\mathrm{a}}$ \\
\hline$b^{*}$ & $16.3 \pm 0.4^{\mathrm{a}}$ & $16.5 \pm 0.4^{\mathrm{ab}}$ & $17.5 \pm 0.4^{\mathrm{b}}$ & $16.6 \pm 0.4^{\mathrm{ab}}$ & $17.5 \pm 0.4^{\mathrm{b}}$ \\
\hline Chroma & $24.0 \pm 0.6^{\mathrm{a}}$ & $24.7 \pm 0.6^{\mathrm{a}}$ & $25.2 \pm 0.5^{\mathrm{a}}$ & $24.1 \pm 0.6^{\mathrm{a}}$ & $25.4 \pm 0.6^{\mathrm{a}}$ \\
\hline Hue & $0.79 \pm 0.01^{\mathrm{ab}}$ & $0.73 \pm 0.01^{\mathrm{a}}$ & $0.77 \pm 0.01^{\mathrm{c}}$ & $0.76 \pm 0.01^{\mathrm{bc}}$ & $0.76 \pm 0.01^{b c}$ \\
\hline Ratio (R630/580) & $4.0 \pm 0.2^{\mathrm{a}}$ & $4.3 \pm 0.2^{\mathrm{a}}$ & $4.1 \pm 0.2^{\mathrm{a}}$ & $4.0 \pm 0.2^{\mathrm{a}}$ & $4.3 \pm 0.2^{\mathrm{a}}$ \\
\hline \multicolumn{6}{|l|}{12 days aged } \\
\hline $\mathrm{L}^{*}$ & $35.7 \pm 0.5^{\mathrm{a}}$ & $35.9 \pm 0.5^{\mathrm{ab}}$ & $38.8 \pm 0.4^{\mathrm{c}}$ & $36.7 \pm 0.5^{\mathrm{ab}}$ & $37.1 \pm 0.5^{\mathrm{b}}$ \\
\hline$a^{*}$ & $20.3 \pm 0.5^{\mathrm{ab}}$ & $21.2 \pm 0.5^{\mathrm{b}}$ & $19.9 \pm 0.5^{\mathrm{a}}$ & $19.9 \pm 0.5^{\mathrm{ab}}$ & $19.9 \pm 0.5^{\mathrm{ab}}$ \\
\hline$b^{*}$ & $19.1 \pm 0.3^{\mathrm{a}}$ & $19.6 \pm 0.3^{\mathrm{ab}}$ & $20.0 \pm 0.2^{\mathrm{b}}$ & $19.0 \pm 0.3^{\mathrm{a}}$ & $19.3 \pm 0.3^{\mathrm{ab}}$ \\
\hline Chroma & $27.9 \pm 0.5^{\mathrm{a}}$ & $28.9 \pm 0.5^{\mathrm{a}}$ & $28.2 \pm 0.5^{\mathrm{a}}$ & $27.6 \pm 0.5^{\mathrm{a}}$ & $27.8 \pm 0.5^{\mathrm{a}}$ \\
\hline Hue & $0.76 \pm 0.01^{\mathrm{ab}}$ & $0.73 \pm 0.01^{\mathrm{a}}$ & $0.79 \pm 0.01^{\mathrm{c}}$ & $0.76 \pm 0.01^{\mathrm{ab}}$ & $0.77 \pm 0.01^{b c}$ \\
\hline Ratio(R630/580) & $5.6 \pm 0.2^{\mathrm{ab}}$ & $6.0 \pm 0.2^{\mathrm{b}}$ & $5.1 \pm 0.2^{\mathrm{a}}$ & $5.3 \pm 0.2^{\mathrm{ab}}$ & $5.3 \pm 0.2^{\mathrm{a}}$ \\
\hline \multicolumn{6}{|l|}{40 days aged } \\
\hline$L^{*}$ & $37.7 \pm 0.6^{\mathrm{a}}$ & $38.3 \pm 0.6^{\mathrm{a}}$ & $41.0 \pm 0.5^{\mathrm{b}}$ & $39.1 \pm 0.6^{\mathrm{a}}$ & $39.1 \pm 0.6^{\mathrm{a}}$ \\
\hline$a^{*}$ & $16.9 \pm 0.3^{\mathrm{a}}$ & $17.4 \pm 0.3^{\mathrm{a}}$ & $16.5 \pm 0.3^{\mathrm{a}}$ & $17.2 \pm 0.4^{\mathrm{a}}$ & $16.7 \pm 0.3^{\mathrm{a}}$ \\
\hline$b^{*}$ & $16.7 \pm 0.3^{\mathrm{a}}$ & $17.2 \pm 0.3^{\mathrm{ab}}$ & $17.7 \pm 0.2^{\mathrm{b}}$ & $17.5 \pm 0.3^{\mathrm{ab}}$ & $17.3 \pm 0.3^{\mathrm{ab}}$ \\
\hline Chroma & $23.8 \pm 0.4^{\mathrm{a}}$ & $24.5 \pm 0.4^{\mathrm{a}}$ & $24.2 \pm 0.3^{\mathrm{a}}$ & $24.6 \pm 0.4^{\mathrm{a}}$ & $24.1 \pm 0.4^{\mathrm{a}}$ \\
\hline Hue & $0.79 \pm 0.01^{\mathrm{a}}$ & $0.78 \pm 0.01^{\mathrm{a}}$ & $0.82 \pm 0.01^{\mathrm{b}}$ & $0.80 \pm 0.01^{\mathrm{a}}$ & $0.81 \pm 0.01^{\mathrm{ab}}$ \\
\hline Ratio (R630/580) & $4.0 \pm 0.1^{\mathrm{ab}}$ & $4.1 \pm 0.1^{\mathrm{b}}$ & $3.8 \pm 0.1^{\mathrm{a}}$ & $4.1 \pm 0.1^{\mathrm{ab}}$ & $3.9 \pm 0.1^{\mathrm{ab}}$ \\
\hline
\end{tabular}

Predicted means within a row not having a subscript letter in common differ by more than twice the standard error of their difference (i.e. $P<0.05$ ).

${ }^{1}$ chic/arrow - chicory + arrowleaf clover.

${ }^{2}$ luc/phal - lucerne + phalaris. 
Table 5

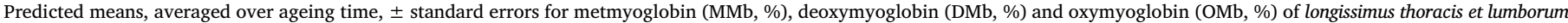
(LL) muscle of White Dorper lambs fed five different forage-types with 3 replicates per forage-type, measured in three different ageing times and four display periods.

\begin{tabular}{|c|c|c|c|c|c|c|}
\hline \multirow[t]{2}{*}{ Traits } & \multirow[t]{2}{*}{ Display period (days) } & \multicolumn{5}{|l|}{ Treatments } \\
\hline & & $\begin{array}{l}\text { Bladder } \\
(\mathrm{n}=12)\end{array}$ & $\begin{array}{l}\text { Brassica } \\
(\mathrm{n}=12)\end{array}$ & $\begin{array}{l}\text { Chic/arrow }{ }^{1} \\
(\mathrm{n}=15)\end{array}$ & $\begin{array}{l}\text { luc/phal } \\
(\mathrm{n}=11)\end{array}$ & $\begin{array}{l}\text { Lucerne } \\
(\mathrm{n}=12)\end{array}$ \\
\hline \multicolumn{7}{|c|}{5 days aged } \\
\hline \multirow[t]{4}{*}{$\mathrm{MMb}$} & 0 & $29.2 \pm 0.7^{\mathrm{a}}$ & $30.1 \pm 0.7^{\mathrm{a}}$ & $30.2 \pm 0.6^{\mathrm{a}}$ & $29.5 \pm 0.7^{\mathrm{a}}$ & $30.6 \pm 0.7^{\mathrm{a}}$ \\
\hline & 1 & $36.0 \pm 0.7^{\mathrm{b}}$ & $35.6 \pm 0.7^{\mathrm{b}}$ & $35.7 \pm 0.6^{\mathrm{b}}$ & $36.2 \pm 0.7^{\mathrm{b}}$ & $35.5 \pm 0.7^{\mathrm{b}}$ \\
\hline & 2 & $41.0 \pm 0.7^{\mathrm{de}}$ & $39.3 \pm 0.7^{\mathrm{cd}}$ & $38.1 \pm 0.6^{\mathrm{c}}$ & $40.9 \pm 0.7^{\mathrm{de}}$ & $38.2 \pm 0.7^{c}$ \\
\hline & 3 & $44.7 \pm 0.7^{\mathrm{h}}$ & $42.2 \pm 0.7^{\mathrm{ef}}$ & $42.9 \pm 0.6^{\mathrm{fg}}$ & $44.5 \pm 0.7^{\mathrm{gh}}$ & $43.7 \pm 0.7^{\mathrm{fgh}}$ \\
\hline \multirow[t]{4}{*}{$\mathrm{DMb}$} & 0 & $39.8 \pm 1.1^{\mathrm{f}}$ & $34.7 \pm 1.1^{\mathrm{e}}$ & $31.2 \pm 1.0^{\mathrm{d}}$ & $34.6 \pm 1.2^{\mathrm{e}}$ & $31.1 \pm 1.1^{\mathrm{d}}$ \\
\hline & 1 & $17.5 \pm 1.1^{\mathrm{ab}}$ & $17.6 \pm 1.1^{\mathrm{ab}}$ & $17.6 \pm 1.0^{\mathrm{ab}}$ & $17.9 \pm 1.2^{\mathrm{abc}}$ & $18.0 \pm 1.1^{\mathrm{abc}}$ \\
\hline & 2 & $20.9 \pm 1.1^{\mathrm{c}}$ & $21.0 \pm 1.1^{\mathrm{c}}$ & $18.0 \pm 1.0^{\mathrm{abc}}$ & $20.2 \pm 1.2^{\mathrm{bc}}$ & $18.6 \pm 1.1^{\mathrm{abc}}$ \\
\hline & 3 & $16.2 \pm 1.1^{\mathrm{a}}$ & $17.1 \pm 1.1^{\mathrm{ab}}$ & $17.3 \pm 1.0^{\mathrm{ab}}$ & $15.7 \pm 1.2^{\mathrm{a}}$ & $16.9 \pm 1.1^{\mathrm{a}}$ \\
\hline \multirow[t]{4}{*}{$\mathrm{OMb}$} & 0 & $31.0 \pm 1.2^{\mathrm{a}}$ & $35.2 \pm 1.2^{\mathrm{b}}$ & $38.6 \pm 1.0^{\mathrm{cd}}$ & $35.9 \pm 1.3^{\mathrm{bc}}$ & $38.3 \pm 1.2^{\mathrm{bcd}}$ \\
\hline & 1 & $46.5 \pm 1.2^{\text {ghi }}$ & $46.8 \pm 1.2^{\mathrm{hi}}$ & $46.7 \pm 1.1^{\mathrm{i}}$ & $45.9 \pm 1.3^{g h i}$ & $46.5 \pm 1.2^{\mathrm{hi}}$ \\
\hline & 2 & $38.1 \pm 1.2^{\mathrm{bcd}}$ & $39.7 \pm 1.2^{\mathrm{d}}$ & $43.9 \pm 1.1^{\mathrm{fgh}}$ & $38.9 \pm 1.3^{\mathrm{cd}}$ & $43.2 \pm 1.2^{\mathrm{efg}}$ \\
\hline & 3 & $39.0 \pm 1.2^{\mathrm{cd}}$ & $40.8 \pm 1.2^{\mathrm{def}}$ & $39.8 \pm 1.1^{\mathrm{d}}$ & $39.8 \pm 1.3^{\mathrm{de}}$ & $39.4 \pm 1.2^{\mathrm{d}}$ \\
\hline \multicolumn{7}{|c|}{12 days aged } \\
\hline \multirow[t]{4}{*}{$\mathrm{MMb}$} & 0 & $33.1 \pm 0.6^{\mathrm{a}}$ & $34.0 \pm 0.6^{\mathrm{ab}}$ & $34.2 \pm 0.6^{\mathrm{ab}}$ & $34.5 \pm 0.6^{\mathrm{abc}}$ & $34.2 \pm 0.6^{\mathrm{ab}}$ \\
\hline & 1 & $36.1 \pm 0.6^{\text {cde }}$ & $34.9 \pm 0.6^{\mathrm{bc}}$ & $35.2 \pm 0.6^{\mathrm{bcd}}$ & $35.1 \pm 0.6^{\mathrm{bcd}}$ & $35.4 \pm 0.6^{\mathrm{bcd}}$ \\
\hline & 2 & $38.4 \pm 0.6^{\mathrm{gh}}$ & $36.6 \pm 0.6^{\mathrm{def}}$ & $37.6 \pm 0.6^{\mathrm{efg}}$ & $38.1 \pm 0.6^{\mathrm{fg}}$ & $37.9 \pm 0.6^{\mathrm{fg}}$ \\
\hline & 3 & $40.9 \pm 0.6^{j}$ & $39.0 \pm 0.6^{\mathrm{ghi}}$ & $40.3 \pm 0.6^{\mathrm{ij}}$ & $40.0 \pm 0.6^{\mathrm{hij}}$ & $40.2 \pm 0.6^{\mathrm{ij}}$ \\
\hline \multirow[t]{4}{*}{$\mathrm{DMb}$} & 0 & $35.7 \pm 1.0^{g}$ & $34.1 \pm 1.0^{\mathrm{efg}}$ & $32.0 \pm 0.9^{\mathrm{e}}$ & $35.3 \pm 1.1^{\mathrm{fg}}$ & $32.6 \pm 1.0^{\mathrm{ef}}$ \\
\hline & 1 & $18.4 \pm 1.0^{\mathrm{ab}}$ & $18.1 \pm 1.0^{\mathrm{a}}$ & $16.6 \pm 0.9^{\mathrm{a}}$ & $17.6 \pm 1.1^{\mathrm{a}}$ & $17.3 \pm 1.0^{\mathrm{a}}$ \\
\hline & 2 & $23.8 \pm 1.0^{\mathrm{cd}}$ & $22.3 \pm 1.0^{\mathrm{cd}}$ & $21.1 \pm 0.9^{\mathrm{bc}}$ & $23.5 \pm 1.1^{\mathrm{cd}}$ & $22.4 \pm 1.0^{\mathrm{cd}}$ \\
\hline & 3 & $21.3 \pm 1.0^{\mathrm{cd}}$ & $24.2 \pm 1.0^{\mathrm{d}}$ & $21.1 \pm 0.9^{\mathrm{bc}}$ & $22.1 \pm 1.1^{\mathrm{cd}}$ & $22.0 \pm 1.0^{\mathrm{cd}}$ \\
\hline \multirow[t]{4}{*}{$\mathrm{OMb}$} & 0 & $31.2 \pm 1.2^{\mathrm{ab}}$ & $31.9 \pm 1.2^{\mathrm{ab}}$ & $33.8 \pm 1.1^{\mathrm{bc}}$ & $30.2 \pm 1.3^{\mathrm{a}}$ & $33.2 \pm 1.2^{\mathrm{ab}}$ \\
\hline & 1 & $45.5 \pm 1.2^{\mathrm{g}}$ & $47.0 \pm 1.2^{g}$ & $48.2 \pm 1.1 \mathrm{~g}$ & $47.3 \pm 1.3^{g}$ & $47.3 \pm 1.2^{\mathrm{g}}$ \\
\hline & 2 & $37.8 \pm 1.2^{\mathrm{de}}$ & $41.1 \pm 1.2^{\mathrm{ef}}$ & $41.4 \pm 1.1^{\mathrm{f}}$ & $38.4 \pm 1.3^{\mathrm{def}}$ & $39.7 \pm 1.2^{\mathrm{def}}$ \\
\hline & 3 & $37.8 \pm 1.2^{\mathrm{de}}$ & $36.8 \pm 1.2^{\mathrm{cd}}$ & $38.6 \pm 1.1^{\text {def }}$ & $37.9 \pm 1.3^{\mathrm{de}}$ & $37.8 \pm 1.2^{\text {de }}$ \\
\hline \multicolumn{7}{|c|}{40 days aged } \\
\hline \multirow[t]{4}{*}{$\mathrm{MMb}$} & 0 & $32.6 \pm 0.7^{\mathrm{a}}$ & $32.4 \pm 0.7^{\mathrm{a}}$ & $32.2 \pm 0.6^{\mathrm{a}}$ & $32.3 \pm 0.7^{\mathrm{a}}$ & $33.0 \pm 0.7^{\mathrm{a}}$ \\
\hline & 1 & $36.8 \pm 0.7^{\mathrm{b}}$ & $36.3 \pm 0.7^{\mathrm{b}}$ & $36.8 \pm 0.6^{\mathrm{b}}$ & $36.9 \pm 0.7^{\mathrm{b}}$ & $37.0 \pm 0.7^{\mathrm{b}}$ \\
\hline & 2 & $40.5 \pm 0.7^{\mathrm{c}}$ & $39.5 \pm 0.7^{\mathrm{c}}$ & $40.1 \pm 0.6^{\mathrm{c}}$ & $39.9 \pm 0.7^{c}$ & $40.5 \pm 0.7^{\mathrm{c}}$ \\
\hline & 3 & $46.2 \pm 0.7^{\mathrm{e}}$ & $44.0 \pm 0.7^{\mathrm{d}}$ & $45.4 \pm 0.6^{\mathrm{de}}$ & $45.0 \pm 0.7^{\mathrm{de}}$ & $46.1 \pm 0.7^{\mathrm{e}}$ \\
\hline \multirow[t]{4}{*}{$\mathrm{DMb}$} & 0 & $31.9 \pm 1.0^{\mathrm{k}}$ & $26.9 \pm 1.0^{\mathrm{j}}$ & $27.5 \pm 0.9^{j}$ & $27.6 \pm 1.1^{\mathrm{j}}$ & $27.8 \pm 1.0^{\mathrm{j}}$ \\
\hline & 1 & $20.1 \pm 1.0^{\mathrm{hi}}$ & $18.1 \pm 1.0^{\mathrm{defgh}}$ & $18.0 \pm 0.9^{\text {defghi }}$ & $19.6 \pm 1.1^{\mathrm{ghi}}$ & $17.9 \pm 1.0^{\mathrm{efgh}}$ \\
\hline & 2 & $13.5 \pm 1.0^{\mathrm{abc}}$ & $16.2 \pm 1.0^{\text {cdef }}$ & $13.3 \pm 0.9^{\mathrm{ab}}$ & $16.0 \pm 1.1^{\mathrm{bcde}}$ & $12.7 \pm 1.0^{\mathrm{a}}$ \\
\hline & 3 & $16.7 \pm 1.0^{\text {defg }}$ & $20.8 \pm 1.0^{\mathrm{i}}$ & $16.0 \pm 0.9^{\text {cde }}$ & $18.9 \pm 1.1^{\mathrm{fghi}}$ & $15.3 \pm 1.0^{\mathrm{bcd}}$ \\
\hline \multirow[t]{4}{*}{$\mathrm{OMb}$} & 0 & $35.5 \pm 1.2^{\mathrm{ac}}$ & $40.7 \pm 1.2^{\text {efg }}$ & $40.4 \pm 1.0^{\text {ef }}$ & $40.1 \pm 1.2^{\mathrm{def}}$ & $39.1 \pm 1.2^{\text {bde }}$ \\
\hline & 1 & $43.1 \pm 1.2^{\mathrm{fgh}}$ & $45.6 \pm 1.2^{\mathrm{hij}}$ & $45.2 \pm 1.0^{\mathrm{hij}}$ & $43.6 \pm 1.2^{\mathrm{ghi}}$ & $45.2 \pm 1.2^{\mathrm{hij}}$ \\
\hline & 2 & $46.0 \pm 1.2^{\mathrm{ij}}$ & $44.3 \pm 1.2^{\text {hij }}$ & $46.6 \pm 1.0^{\mathrm{ij}}$ & $44.1 \pm 1.2^{\mathrm{hij}}$ & $46.9 \pm 1.2 \mathrm{j}$ \\
\hline & 3 & $37.1 \pm 1.2^{\mathrm{abd}}$ & $35.3 \pm 1.2^{\mathrm{a}}$ & $38.6 \pm 1.0^{\text {bde }}$ & $36.1 \pm 1.2^{\mathrm{ab}}$ & $38.6 \pm 1.2^{\text {bcde }}$ \\
\hline
\end{tabular}

Predicted means within a row not having a subscript letter in common differ by more than twice the standard error of their difference (i.e. $P<0.05$ ).

${ }^{1}$ chic/arrow - chicory + arrowleaf clover.

${ }^{2}$ luc/phal - lucerne + phalaris.

+ arrowleaf clover and a lower OMb concentration was observed in LL muscle aged for 12 days, at initial display ( 0 days) for lambs fed lucerne + phalaris.

\section{Discussion}

\subsection{Fatty acid profile}

Brassica forage showed the lowest SFA content throughout the experiment and yet lambs fed brassica had the highest content of short chain FA (10:0, 12:0, 14:0 and 15:0). Ruminant meat is naturally high in SFAs and low in PUFA levels due to biohydrogenation of dietary unsaturated FAs in the rumen. Some forage-types contain a number of phenolic compounds that can reduce the biohydrogenation in the rumen increasing the production of CLA and PUFA (Vasta et al., 2009). Chicory is rich in phenolic compounds (Sincovič et al., 2015), and in this study chicory + arrowleaf and brassica had higher levels of 18:2 $\omega-6 t$ in the LL than the other forage-types, however this did not translate into a difference in total PUFA (Table 2).

The content of total SFA in the LL for all experimental lambs, regardless of forage-type, was higher on average than those reported by
Nuernberg, Fischer, Nuernberg, Ender, \& Dannenberger (2008) for lambs grazed on grass pasture $(737 \mathrm{mg} / 100 \mathrm{~g}$ wet weight) and Kitessa et al. (2010) for lambs finished on irrigated kikuyu pasture (765 mg/100 g of meat). Nevertheless, the level was lower than that reported by Ponnampalam et al. (2012) for lambs fed perennial pasture (1364 mg/100 g of meat). A high content of SFA has been associated with increased plasma cholesterol and plasma low-density lipoprotein levels in consumers, and it is therefore recognised as a major risk in developing coronary heart disease (Department of Health, 1994), except for 18:0 which does not influence cholesterol levels ( $\mathrm{Hu}$, Manson, \& Willett, 2001; Hunter, Zhang, \& Kris-Etherton, 2010).

The concentration of alpha linolenic (18:3 omega-3 ALA) was greater for LL muscle of lambs fed chicory + arrowleaf clover and brassica than the other forage-types. This suggests that the ALA provided by chicory + arrowleaf clover and brassica was better digested and absorbed by the animal and was fixed in muscles at a higher rate. By comparison, AF muscle of lambs fed bladder clover had the lowest ALA concentration, which was expected since bladder clover had the lowest content of this fatty acid. ALA is also a precursor of DHA and EPA (Kitessa et al., 2010) and the high concentration of ALA in LL muscles of lambs fed chicory + arrowleaf clover may explain the 
greater concentration of EPA and DHA and thus the high concentration of health claimable FA (EPA + DHA) in muscle of lambs fed this foragetype. In several studies of sheep meat, the level of EPA + DHA ranged from 20 to $40 \mathrm{mg} / 100 \mathrm{~g}$ of meat (Nuernberg et al., 2008; Kitessa et al., 2010; Ponnampalam et al., 2010; Ponnampalam et al., 2012; Ponnampalam et al., 2014). These reflected the findings in the current experiment for which meat from all treatments exceeded the EPA + DHA level of $26 \mathrm{mg} / 100 \mathrm{~g}$ of meat, the minimum EPA + DHA level considered the cut-off point to claim lamb meat as a 'source' of omega-3 fatty acids (Pannier et al., 2010).

Long chain omega-3 PUFAs are considered very important for the human diet and have been linked with immune system regulation, they aid brain functions and development of vision in foetuses (Simopoulos, 2002). Lambs fed chicory + arrowleaf clover showed the highest level of $\omega-3$ in both the LL and AF muscles, however the levels were not significantly different to those in the LL muscle of lambs fed brassica or lucerne + phalaris and in both muscles of lambs fed lucerne. This reflects the high content of $\omega-3$ (above $30 \mathrm{mg} / 100 \mathrm{~g}$ ) found in these pastures, compared to bladder clover, which had the lowest levels of $₫$ 3 throughout the experiment. The $\mathrm{LL}$ and $\mathrm{AF}$ muscles from all combinations of forage-type $x$ muscles had a $₫-6: \Phi-3$ ratio below 4 , which is the maximum limit of the $₫-6: \bowtie-3$ ratio considered to be detrimental to health in the human diet (Department of Health, 1994). With the exception of lambs grazing bladder clover that had highest $\Phi$ 6:@-3 ratio, all other treatments had $\omega-6: \oplus-3$ ratios which were consistent with the literature reported values (Fraser, Speijers, Theobald, Fychan, \& Jones, 2004; Aurousseau et al., 2007; Joy, Ripoll, Molino, Dervishi, \& Álvarez-Rodriguez, 2012; Ponnampalam et al., 2012; Ramírez-Retamal, Morales, Martínez, \& Barra, 2014). However, all treatments had a by Díaz et al. (2002); Joy, Ripoll, and Delfa (2008); Nuernberg et al. (2008); Scerra et al. (2011); and Ricardo et al. (2015). The higher $₫-$ 6:®-3 ratio concentration in LL and AF muscle for lambs fed bladder clover reflects the higher concentration of $\omega-6$ fatty acids and the lower concentration of $₫-3$ in the plant compared with the other forage-types.

\subsection{Lipid oxidation, vitamin E, carbonyl, nitrite and nitrate content}

As expected, the TBARS values in this study increased over the ageing time and all treatments had TBARS values below 4.2 MDA.mg/ $\mathrm{kg}$, except for meat from lambs fed bladder clover, chicory + arrowleaf clover and lucerne measured after 40 days of ageing. This may have occurred due to the lower concentration of vitamin $\mathrm{E}$ in these forage crops that was insufficient to prevent lipid oxidation during the retail display, especially for the long ageing period. High TBARS values in meat are undesirable since it leads to the development of rancid odours and off-flavour (Howes, Bekhit, Burritt, \& Campbell, 2015), with panellists detecting off-flavours and rancidity on lean muscle at levels of $0.5 \mathrm{mg} \mathrm{MDA} / \mathrm{kg}$ (Berruga, Vergara, \& Gallego, 2005). However, the low levels of intramuscular fat (IMF) in LL and AF muscles and the lack of significant difference for sensory panel evaluation (LL muscle aged for 5 days), as showed in the early report by De Brito et al. (2016), may indicate that TBARS values aged for 5 days do not have any effect on sensory panel evaluation. By contrast, Berruga et al. (2005) reported that TBARS levels ranging from 4.2 to $7.5 \mathrm{mg}$ of MDA mg $/ \mathrm{kg}$ of muscle decreased the acceptability of lamb meat and suggested this was due to the high level of TBARS and also the sensory panellists detecting slight off-odours.

One strategy to reduce lipid oxidation is to increase the vitamin $\mathrm{E}$ content in diets (Descalzo \& Sancho, 2008). Vitamin E is a lipid soluble compound, and it is known to protect myoglobin and PUFAs from oxidation and thus extend the shelf life of meat (Faustman, Chan, Schaefer, \& Havens, 1998). The results from the current study indicated that forage-types with higher vitamin E content (brassica or lucerne + phalaris) also had reduced lipid oxidation as assessed by TBARS values, independent of ageing time. The concentrations of vitamin $\mathrm{E}$ in the current study were lower than those found in the LL muscle reported by Hopkins, Lamb, Kerr, van de Vem, \& Ponnampalam (2013) from lambs fed lucerne pasture with either oats or lupins (3.8 mg/kg). Further, Ponnampalam et al. (2012) also found higher vitamin $\mathrm{E}$ content in the meat of lambs grazing perennial pasture (5.88 $\mathrm{mg} / \mathrm{kg}$ meat), than for lambs fed annual pasture with lucerne hay and oat grain $(3.43 \mathrm{mg} / \mathrm{kg}$ meat $)$ or flaxseed $(3.10 \mathrm{mg} / \mathrm{kg}$ meat $)$ or flaxmeal ( $3.63 \mathrm{mg} / \mathrm{kg}$ meat), however there was no effect on oxidative stability. In the present experiment, lambs fed brassica and lucerne + phalaris had vitamin E values above $2.95 \mathrm{mg} / \mathrm{kg}$ suggesting that those treatments may help prevent lipid oxidation in meat as suggested by Ponnampalam et al. (2012) where it was suggested that the vitamin E content should be above $2.95 \mathrm{mg} / \mathrm{kg}$ of muscle. Higher residual levels of vitamin $\mathrm{E}$ in meat of lambs fed brassica could be due to the higher content of vitamin $\mathrm{E}$ observed for this pasture. The lucerne + phalaris pasture had a higher vitamin $\mathrm{E}$ content at the beginning of the experiment however, it exhibited a decline as the experiment continued. By comparison, brassica crops had a more consistent vitamin $\mathrm{E}$ content over the experimental period, which likely explains the higher level reflected in the LL muscle of lambs fed this forage-type.

Nitrite and nitrate are generally used as artificial preservatives in processed meat to stabilise meat colour and inhibit microorganism growth; they can also be an important indicator of protein degradation (Noel, Briand, \& Dumont, 1990; Kanner, 1994; Iammarino \& Di Taranto, 2012). Nitrite and nitrate content were higher in LL muscle at 12 and 40 days aged than in 5 days aged LL. Free nitrite and nitrate values are reported to increase with an increase in ageing time, which is indicative of protein degradation. Due to the interaction between secondary amines, nitrites and the synthesis of $\mathrm{N}$-nitroso compounds in the stomach, the high consumption of these compounds is associated with gastric cancer in humans (Archer, 1989; Iammarino \& Di Taranto, 2012). The highest nitrite content was observed in LL muscle of lambs fed brassica, lucerne + phalaris and lucerne in all ageing periods, while the highest nitrate values were found in LL muscles of lambs fed lucerne + phalaris for all ageing times.

\subsection{Retail display colour}

Luminosity was highest for meat from lambs fed chicory + arrowleaf clover while lambs fed bladder clover showed the lowest luminosity values $\left(\mathrm{L}^{*}\right)$, irrespective of ageing period prior to display $(5,12$ or 40 days aged). In addition, all treatments (forage-type) had values of luminosity above 35.7, even following an observed decline in luminosity for meat aged from 5 to 12 days. Interactions between increased lipid and colour oxidation have previously been reported (Nute et al., 2007), suggesting that elevated concentrations of SFA can affect the meat colour characteristics over retail display. However, the present study shows that lambs fed chicory + arrowleaf clover also had higher concentration of EPA + DHA and MUFA and this did not affect the meat luminosity. In contrast, meat from brassica and lucerne fed lambs also had a higher concentration of EPA + DHA and MUFA with intermediary values of $L^{*}$ across all ageing periods compared to the other forage-types. Similarly, Hopkins et al. (2014) did not find an effect of elevated SFA on LL muscle retail colour in lambs, fed with algae.

It has been established that the vitamin E concentration of the meat can influence meat colour stability (Wulf et al., 1995; Ponnampalam et al., 2012). In this study, the forage-type and the ageing time did not influence the meat colour parameters redness (a*) after 5 and 40 days of ageing, ratio (R630/580) for meat 5 days aged and chroma for all ageing times, which agrees with De Brito et al. (2016) who showed the fresh colour of LL muscle did not differ between the treatments. This may have occurred due to the low level of vitamin E in the in LL muscle when compared to Ponnampalam et al. (2012) and Hopkins et al. (2013). In addition, the difference in vitamin $\mathrm{E}$ content between the forage-types, even in concentrations sufficient to prevent lipid oxida- 
tion, did not affect the a* and ratio meat colour parameters. However, the LL muscle from lambs fed brassica had the highest concentration of Vitamin E and showed higher values of redness (a*) in LL muscle 12 days aged when compared to the other forage-types.

The reflectance ratio (R630/580 nm) is a measurement of brownness, which reflects higher concentrations of metmyoglobin in meat (Ponnampalam et al., 2012) and can be used as a predictor of meat quality. A number of authors have suggested that the threshold for consumer acceptance of colour occurs with a R630/580 below 3.3 (Khliji, van de Ven, Lamb, Lanza, \& Hopkins, 2010) to below 3.0 (Toohey \& Hopkins, 2006; Jacob, D'Antuono, Smith, Pethick, \& Warner, 2007) in order for consumers perceive unacceptable brown colour. Lamb meat for any forage-type studied in this experiment had values of reflectance on average above 3.3 at each ageing period averaged over the display period, but these values would approach the critical level at the end of the display period. Any differences between the forage-types for LL muscle 5 days aged, did not affect sensory characteristics as reported by De Brito et al., 2016. Higher hue values were found in meat of lambs fed chicory + arrowleaf clover for all ageing times and is indicative of browning as well as the increase of hue value over the ageing time in the present experiment. The hue angle value is correlated with metmyoglobin accumulation (Luciano et al., 2011) and the MMb is formed from conversion of OMb to MMb that occurs with increased exposure to oxygen and results in meat discoloration (Faustman \& Cassens, 1990).

Jose, Jacob, Pethick, \& Gardner (2016) suggested that a vitamin E level of $3.0 \mathrm{mg} / \mathrm{kg}$ muscle would reduce the formation of MMb. In the current study the forage-types that resulted in the highest vitamin $\mathrm{E}$ levels in the muscle (brassica and lucerne + phalaris) tended to lead to lower levels of $\mathrm{MMb}$ in the meat particularly after 40 days of ageing. However, the higher vitamin E level of brassica and lucerne + phalaris did not prevent MMb formation in this study.

\section{Conclusion}

The current study indicates that chicory + arrowleaf clover provided a high level of SFA, but also resulted in a higher concentration of health claimable (EPA + DHA) and $\omega-3$ PUFAs in lamb muscle. This was mirrored by a decrease in $\omega-6$ PUFAs and the $\omega-6: \omega-3$ ratio that is considered good for human health. Therefore, the authors suggest chicory + arrowleaf clover as a novel forage-type to improve the fatty acid profile of lamb meat. Likewise, the high vitamin E concentration in LL muscle from lambs fed the common forage-type lucerne + phalaris improved the oxidative stability and reduced the conversion of $\mathrm{OMb}$ to $\mathrm{MMb}$, which would consequently slow colour deterioration and improve shelf-life.

\section{Acknowledgments}

The first author acknowledges the NSW Department of Primary Industries, Centre for Red Meat \& Sheep Development - Cowra Australia for hosting her as a PhD student from Brazil. The first author is thankful to CAPES (Coordination for the Improvement of Higher Education Personnel) for scholarship funding in Brazil (15/2014) and Australia (3337/15-4). The authors are grateful for the technical support of Ms. Tracy Lamb, Ms. Jordan Hoban and Mr. Matthew Kerr (NSW DPI); Mr. Isaac James and Mr. Timothy Morley-Sattler (CSU) and the cooperation of the abattoir. The financial support of Meat and Livestock Australia for the grazing experiment is gratefully acknowledged.

\section{References}

Álvarez, I., De La Fuente, J., Cañeque, V., Lauzurica, S., Pérez, C., \& Díaz, M. T. (2009). Changes in the fatty acid composition of $m$. longissimus dorsi of lamb during storage in a high-oxygen modified atmosphere at different levels of dietary vitamin $\mathrm{E}$ supplementation. Journal of Agricultural and Food Chemistry, 57, 140-146.

AMSA (2012). Meat color measurement guidelines. In M. Hunt, \& D. King (Eds.), Champaign (pp. 133-). Illinois USA: American Meat Science Association (December 2012 ed.).

Anonymous (2005). Handbook of Australian meat(7th ed.). Brisbane, Australia: AUS-MEAT Limited.

Archer, M. C. (1989). Mechanisms of action of N-nitroso compounds. Cancer Surveys, 8 , 241-250.

Aurousseau, B., Bauchart, D., Galot, A. L., Prache, S., Micol, D., \& Priolo, A. (2007). Indoor fattening of lambs raised on pasture: 2 . Influence of stall finishing duration on triglyceride and phospholipid fatty acids in the longissimus thoracis muscle. Meat Science, 76, 417-427.

Berruga, M. I., Vergara, H., \& Gallego, L. (2005). Influence of packaging conditions on microbial and lipid oxidation in lamb meat. Small Ruminant Research, 57, 257-264. Cold Spring Harbor Protocols (2009). Tissue lysis buffer. (Pdb.rec11948).

Cook, C. W. (1964). Symposium on nutrition of forages and pastures: Collecting forage samples representative of ingested material of grazing animals for nutritional studies. Journal of Animal Science, 23, 265-270.

Cooper, S. L., Sinclair, L. A., Wilkinson, R. G., Hallett, K. G., Enser, M., \& Wood, J. D. (2004). Manipulation of the n-3 polyunsaturated fatty acid content of muscle and adipose tissue in lambs. Journal of Animal Science, 82, 1461-1470.

R Core Team (2015). R: A language and environment for statistical computing. Vienna, Austria: R Foundation for Statistical Computing. Retrieved from http://www. Rproject.org/.

CSIRO (2007). Nutrient requirements of domesticated ruminants. Melbourne, Australia: CSIRO Publishing.

De Brito, G. F., McGrath, S. R., Holman, B. W. B., Friend, M. A., Fowler, S. M., van de Ven, R. J., \& Hopkins, D. L. (2016). The effect of forage type on lamb carcass traits, meat quality and sensory traits. Meat Science, 119, 95-101.

De La Fuente, J., Díaz, M. T., Álvarez, I., Lauzurica, S., Cañeque, V., \& Pérez, C. (2007), Effect of dietary supplementation with vitamin $\mathrm{E}$ on characteristics of vacuum-packed lamb. Journal of the Science of Food and Agriculture, 87, 651-659.

Department of Health (1994). Nutritional aspects of cardiovascular disease. Report on health and social subjects. London: no. 46. H. M. Stationery Office.

Descalzo, A. M., \& Sancho, A. M. (2008). A review of natural antioxidants and their effects on oxidative status, odor and quality of fresh beef produced in Argentina. Meat Science, 79, 423-436.

Díaz, M. T., Velasco, S., Cañeque, V., Lauzurica, S., Ruiz, H. F., Pérez, C., González, J., \& Manzanares, C. (2002). Use of concentrate or pasture for fattening lambs and its effect on carcass and meat quality. Small Ruminant Research, 43, 257-268.

FAO Food and Agriculture Organization of the United Nations (2013). Diet, Nutrition and the Prevention of Chronic Diseases.. ftp://ftp.fao.org/docrep/fao/005/ac911e/ ac911e00.pdf.

Faustman, C., \& Cassens, R. G. (1990). The biochemical basis for discoloration in fresh meat: A review. Journal of Muscle Foods, 1, 217-243.

Faustman, C., Chan, W. K. M., Schaefer, D. M., \& Havens, A. (1998). Beef colour update. The Role of Vitamin E. Journal Of Animal Science, 76, 1019-1026.

Fisher, A. V., Enser, M., Richardson, R. I., Wood, J. D., Nute, G. R., Kurt, E., Sinclair, L. A., \& Wilkinson, R. G. (2000). Fatty acid composition and eating quality of lamb types derived from four diverse breed x production systems. Meat Science, 55, 141-147.

Fraser, M. D., Speijers, M. H. M., Theobald, V. J., Fychan, R., \& Jones, R. (2004). Production performance and meat quality of grazing lambs finished on red clover, lucerne or perennial ryegrass swards. Grass and Forage Science, 59, 345-356.

Hopkins, D. L., Clayton, E. H., Lamb, T. A., van de Ven, R. J., Refshauge, G., Kerr, M. J., Bailes, K., Lewandowski, P., \& Ponnampalam, E. N. (2014). The impact of supplementing lambs with algae on growth, meat traits and oxidative status. Meat Science, 98, 135-141.

Hopkins, D. L., Lamb, T. A., Kerr, M. J., van de Ven, R. J., \& Ponnampalam, E. N. (2013). Examination of the effect of ageing and temperature at rigor on colour stability of lamb meat. Meat Science, 95, 311-316.

Howes, N. L., Bekhit, A. E. A., Burritt, D. J., \& Campbell, A. W. (2015). Opportunities and implications of pasture-based lamb fattening to enhance the long-chain fatty acid composition in meat. Comprehensive Reviews in Food Science and Food Safety, 14, $22-36$.

Hu, F., Manson, J., \& Willett, W. (2001). Types of dietary fat and risk of coronary heart disease: A critical review. Journal of the American College of Nutrition, 20, 5-19.

Hunter, J., Zhang, J., \& Kris-Etherton, P. (2010). Cardiovascular disease risk of dietary stearic acid compared with trans, other saturated, and unsaturated fatty acids: A systematic review. The American Journal of Clinical Nutrition, 91, 46-63.

Iammarino, M., \& Di Taranto, A. (2012). Nitrite and nitrate in fresh meats: A contribution to the estimation of admissible maximum limits to introduce in directive 95/2/EC. International Journal of Food Science and Technology, 47, 1852-1858.

Jacob, R. H., D'Antuono, M. F., Smith, G. M., Pethick, D. W., \& Warner, R. D. (2007) Effect of lamb age and electrical stimulation on the colour stability of fresh lamb meat. Australian Journal of Agricultural Research, 58, 374-382.

Jose, C. G., Jacob, R. H., Pethick, D. W., \& Gardner, G. E. (2016). Short term supplementation rates to optimise vitamin $\mathrm{E}$ concentration for retail colour stability of Australian lamb meat. Meat Science, 111, 101-109.

Joy, M., Ripoll, G., \& Delfa, R. (2008). Effects of feeding system on carcass and non carcass composition of Churra Tensina light lambs. Small Ruminant Research, 78 123-133.

Joy, M., Ripoll, G., Molino, F., Dervishi, E., \& Álvarez-Rodriguez, J. (2012). Influence of the type of forage supplied to ewes in pre- and post-partum periods on the meat fatty acids of suckling lambs. Meat Science, 90, 775-782.

Kanner, J. (1994). Oxidative process in meat and meat products: Quality implications. Meat Science, 36, 169-189. 
Khliji, S., van de Ven, R., Lamb, T. A., Lanza, M., \& Hopkins, D. L. (2010). Relationship between consumer ranking of lamb colour and objective measures of colour. Meat Science, 85, 224-229.

Kitessa, S., Liu, S., Briegel, J., Pethick, D., Gardner, G., Ferguson, M., Allingham, P., Nattrass, G., McDonagh, M., Ponnampalam, E., \& Hopkins, D. L. (2010). Effects of intensive or pasture finishing in spring and linseed supplementation in autumn on the omega-3 content of lamb meat and its carcass distribution. Animal Production Science, 50, 130-137.

Luciano, G., Biondi, L., Pagano, R. I., Scerra, M., Vasta, V., López-Andrés, P., Valenti, B., Lanza, M., Priolo, A., \& Avondo, M. (2012). The restriction of grazing duration does not compromise lamb meat colour and oxidative stability. Meat Science, 92, 30-35.

Luciano, G., Vasta, V., Monahan, F. J., López-Andrés, P., Biondi, L., Lanza, M., \& Priolo, A. (2011). Antioxidant status, colour stability and myoglobin resistance to oxidation of longissimus dorsi muscle from lambs fed a tannin-containing diet. Food Chemistry, 124, 1036-1042.

McGrath, S., Sandral, G., \& Friend, M. (2015). Lamb growth rates on pasture: Assessing options for finishing lambs in spring. Proceedings of Australian society of agronomy conference. 17, (pp. 1-4).

McMurray, C. H., \& Blanchflower, W. J. (1979). Application of a high-performance liquid chromatographic fluorescence method for the rapid determination of $\alpha$-tocopherol in the plasma of cattle and pigs and its comparison with direct fluorescence and highperformance liquid chromatography-ultraviolet detection methods. Journal of Chromatography A, 178, 525-531.

Morrissey, P. A., Sheehy, P. J. A., Galvin, K., Kerry, J. P., \& Buckley, D. J. (1998). Lipid stability on meat and meat products. Meat Science, 49, 73-86.

Mortimer, S. I., van der Werf, J. H. J., Jacob, R. H., Hopkins, D. L., Pannier, L., Pearce, K. L., Gardner, G. E., Warner, R. D., Geesink, G. H., Hocking Edwards, J. E., Ponnampalam, E. N., Ball, A. J, Gilmour, A. R, \& Pethick, D. W. (2014). Genetic parameters for meat quality traits of Australian lamb meat. Meat Science, 96, 1016-1024.

Noel, P., Briand, E., \& Dumont, J. P. (1990). Role of nitrite in flavour development in uncooked cured meat products: Sensory assessment. Meat Science, 28, 1-8.

Nuernberg, K., Fischer, A., Nuernberg, G., Ender, K., \& Dannenberger, D. (2008). Meat quality and fatty acid composition of lipids in muscle and fatty tissue of Skudde lambs fed grass versus concentrate. Small Ruminant Research, 74, 279-283.

Nute, G. R., Richardson, R. I., Wood, J. D., Hughes, S. I., Wilkinson, R. G., Cooper, S. L., \& Sinclair, L. A. (2007). Effect of dietary oil source on the flavour and the colour and lipid stability of lamb meat. Meat Science, 77, 547-555.

Packer, E. L., Clayton, E. H., \& Cusack, P. M. V. (2011). Rumen fermentation and liveweight gain in beef cattle treated with monensin and grazing lush forage. Australian Veterinary Journal, 89, 338-345.

Pannier, L., Ponnampalam, E. N., Gardner, G. E., Hopkins, D. L., Ball, A. J., Jacob, R. H., Pearce, K. L., \& Pethick, D. W. (2010). Prime Australian lamb supplies key nutrients for human health. Animal Production Science, 50, 1115-1122.

Ponnampalam, E. N., Warner, R. D., Kitessa, S., McDonagh, M. B., Pethick, D. W., Allen, D., \& Hopkins, D. L. (2010). Influence of finishing systems and sampling site on fatty acid composition and retail shelf-life of lamb. Animal Production Science, 50, 775-781.

Ponnampalam, E. N., Burnett, V. F., Norng, S., Hopkins, D. L., Plozza, T., \& Jacobs, J. L. (2016). Muscle antioxidant (vitamin E) and major fatty acid groups, lipid oxidation and retail colour of meat from lambs fed a roughage based diet with flaxseed or algae. Meat Science, 111, 154-160.
Ponnampalam, E. N., Burnett, V. F., Norng, S., Warner, R. D., \& Jacobs, J. L. (2012). Vitamin $\mathrm{E}$ and fatty acid content of lamb meat from perennial pasture or annual pasture systems with supplements. Animal Production Science, 52, 255-262.

Ponnampalam, E. N., Butler, K. L., Pearce, K. M., Mortimer, S. I., Pethick, D. W., Ball, A. J., \& Hopkins, D. L. (2014). Sources of variation of health claimable long chain omega-3 fatty acids in meat from Australian lamb slaughtered at similar weights. Meat Science, 96, 1095-1103.

Ponnampalam, E. N., Trout, G. R., Sinclair, A. J., Egan, A. R., \& Leury, B. J. (2001). Comparison of the color stability and lipid oxidative stability of fresh and vaccum packaged lamb muscle containing elevated omega-3 and omega- 6 fatty acid levels from dietary manipulation. Meat Science, 58, 151-161.

Ramírez-Retamal, J., Morales, R., Martínez, M. E., \& Barra, R. D. L. (2014). Effect of the type of pasture on the meat characteristics of Chilote lambs. Food and Nutrition Sciences, 5, 635-644.

Ricardo, H. A., Fernandes, A. R. M., Mendes, L. C. N., Oliveira, M. A. G., Protes, V. M., Scatena, E. M., Roca, R. O., Athayde, N. B., Girao, L. V. C., \& Alves, L. G. C. (2015), Carcass traits and meat quality differences between a traditional and an intensive production model of market lambs in Brazil: Preliminary investigation. Small Ruminant Research, 130, 141-145.

Robinson, S., Kerven, C., Behnke, R., Kushenov, K., \& Milner-Gulland, E. J. (2016). The changing role of bio-physical and socio-economic drivers in determining livestock distributions: A historical perspective from Kazakhstan. Agricultural Systems, 143, $169-182$.

Scerra, M., Luciano, G., Caparra, P., Foti, F., Cilione, C., Giorgi, A., \& Scerra, V. (2011). Influence of stall finishing duration of Italian merino lambs raised on pasture on intramuscular fatty acid composition. Meat Science, 89, 238-242.

Sigma-Aldrich (2015a). Nitrite/nitrate assay kit, colorimetric. Technical Bulletin, 23479 (www.sigmaaldrich.com).

Sigma-Aldrich (2015b). Protein Carbonyl Content Assay Kit, colorimetric. Technical BulletinMAK094 (www.sigmaaldrich.com).

Simopoulos, A. (2002). Omega-3 fatty acids in inflammation and autoimune diseases. Journal of the American College of Nutrition, 21, 495-505.

Sincovič, L., Demšar, L., Znidarcic, D., Vidrih, R., Hribar, J., \& Treutter, D. (2015). Phenolic profiles in leaves of chicory cultivars (Cichorium intybus L.) as influenced by organic and mineral fertilizers. Food Chemistry, 166, 507-513.

Toohey, E. S., \& Hopkins, D. L. (2006). The impact of new generation pre-dressing midvoltage electrical stimulation on colour stability. In proceedings 52nd international congress of meat science and technology (pp. 627-628). Ireland: Dublin.

Vasta, V., Mele, M., Serra, A., Scerra, M., Luciano, G., Lanza, M., \& Priolo, A. (2009). Metabolic fate of fatty acids involved in ruminal biohydrogenation in sheep fed concentrate or herbage with or without tannins. Journal of Animal Science, 87, 2674-2684.

Wood, J. D., \& Enser, M. (1997). Factors influencing fatty acids in meat and the role of antioxidants in improving meat quality. British Journal of Nutrition, 78, 49-60.

Wulf, D. M., Morgan, J. B., Sanders, S. K., Tatum, J. D., Smith, G. C., \& Williams, S. (1995). Effects of dietary supplementation of Vitamin E on storage and caselife properties of lamb retail cuts. Journal of Animal Science, 73, 399-405.

Zeptometrix (2006). Thiobarbituric Acid Reactive Substances. OXItek TBARS assay kit, Revision 2, 1-11.

Zervas, G., \& Tsiplakou, E. (2011). The effect of feeding systems on the characteristics of products from small ruminants. Small Ruminant Research, 101, 140-149. 